DOI: https://doi.org/10.35387/ucj.2(2).2020.13-17

KYRYL KOTUN

\title{
LEGISLATIVE SUPPORT OF TEACHER PROFESSIONAL DEVELOPMENT IN UKRAINE
}

\begin{abstract}
Modern education acquires qualitative transformations, adapting to new conditions. Institutions of postgraduate pedagogical education and methodological services are undergoing a thorough reorientation, to overcome a number of stereotypes in the system of teacher professional development before calling for educational services to improve the skills of newly established professional educational associations and NGOs. However, today not only is the problem of inconsistency of the current education system with new needs exacerbated, but also traditions and connections are being broken. Therefore, it is necessary to maintain cooperation between educational institutions and build new cooperation with communities in the regions, without losing the potential of institutions of postgraduate pedagogical education. The New Ukrainian School is changing the entire education system and the teacher, who must be an agent of change, a provider of educational reform, a community leader. These changes affect the system of postgraduate education, causing a new content and technological burden on the teacher professional development. The basis of teacher professional development is the awareness of all transformations in education as a natural need to constantly improve their skills, to form and develop a professional worldview and pedagogical consciousness. The article outlines the features of legislative support for the teacher professional development in Ukraine. Several ways of implementing parts of the new law of Ukraine "On Education" on teacher professional development are substantiated (for example, change of forms of teacher professional development, change of mentality, financing of professional development, formation of a plan of teacher professional development etc.). The functional activities of the future Centres for Teacher Professional Development, which will replace the current methodical offices, as well as the concept of "professional development" are briefly outlined.

Key words: professional development, teacher, pedagogical staff, ways of professional development, centres of professional development, Law of Ukraine «On Education», Ukraine.
\end{abstract}

\section{ЗАКОНОДАВЧЕ ЗАБЕЗПЕЧЕННЯ ПРОФЕСІЙНОГО РОЗВИТКУ ВЧИТЕЛЯ В УКРАЇНІ}

Анотація. Загалом, освіта набуває якісних перетворень, адаптуючись до нових умов. Грунтовної переорієнтації зазнають заклади післядипломної педагогічної освіти та методичні служби, покликані подолати ряд стереотипів у системі підвищення кваліфікації педагога перед викликом освітніх послуг щодо підвищення кваліфікації новостворених професійних освітніх об'єднань і громадських організацій. Проте сьогодні не тільки загострюється проблема невідповідності чинної системи освіти новим потребам, а й порушуються традиції і зв'язки. Тому варто зберегти співпрацю між закладами освіти та побудувати нові взаємини з громадами в регіонах, не втративши потенціалу закладів післядипломної педагогічної освіти. Нова українська школа змінює всю систему освіти і самого вчителя, який має бути агентом змін, провайдером освітньої реформи, лідером громади. Ці зміни впливають і на систему післядипломної освіти, спричиняючи нове змістове і технологічне навантаження на професійний розвиток фахівців у освітній галузі. В основу професійного розвитку вчителя покладено усвідомлення всіх перетворень в освіті як природної потреби постійно підвищувати свою кваліфікацію, формувати та розвивати професійний світогляд і педагогічну свідомість. У статті окреслено особливості законодавчого забезпечення професійного розвитку вчителів в Україні. Обгрунтовано декілька шляхів впровадження частин нового закону Україні «Про освіту» щодо професійного розвитку вчителів (наприклад, зміна форм підвищення кваліфікації, зміна ментальності, фінансування підвищення кваліфікації, формування плану підвищення кваліфікації). Коротко окреслено функціональну діяльність майбутніх Центрів для професійного розвитку вчителів, що замінять теперішні методичні кабінети, а також поняття «професійний розвиток».

Ключові слова: професійний розвиток, вчитель, педагогічні працівники, шляхи професійного розвитку, центри професійного розвитку, Закон України «Про освіту», Україна.

Introduction. In 2017, the education system of Ukraine was reformed with the adoption of the law «On Education». All institutions that offer teacher training services should implement different approaches to teacher life- long professional development based on international best practices. The system of postgraduate pedagogical education should offer each teacher an individual approach to professional development that meets his/her needs 
and ensures the diversification of educational resources and their quality. Provides teacher professional development with the use of new educational and professional programs is the standardization of various forms of postgraduate education: formal, non-formal, informal, as well as a gradual transfer to teacher certification, free choice in terms, topics, forms of education (full-time, distance, mixed).

Professional development is the process of forming the subject of professional activity, the system of certain properties in the conditions of lifelong professional education, selfeducation and professional activity. In the process of professional development, a person masters a system of professionally important qualities, which includes communicative, motivational, characterological, reflective, educational, intellectual, psychophysiological properties of human. During professional development are formed the world view, ethical qualities, special scientific, technical, technological knowledge, skills, abilities of the specialist. There are several stages and results of individual professional development: professional self-determination and choice of profession, training and formation of personal readiness to master the profession, professional education, competence, skills, masters, culture of the specialist (Encyclopedia of Education, 2008).

The aim of the study is to analyse the legislative features of teacher professional development in Ukraine.

Theoretical basis and research methods. The theoretical basis of the study are the scientific works of Ukrainian researchers (L. Lukianova, N. Nychkalo, L. Khomych, H. Sotska, O. Trynus, N. Avsheniuk, O. Ogienko, T. Sorochan, V. Luniachek etc.), The Law of Ukraine "On Education», bylaws of the Ministry of Education and Science of Ukraine, scientific reports etc. In the study was used an interrelated theoretical research methods (analysis, synthesis, individualization and generalization), which provided the possibility of interdisciplinary analysis of the problem.

Results. In 2017, the new Law of Ukraine "On Education» have provided the changes in the system of postgraduate pedagogical education. The analysis of the Law, taking into account the practice of teacher professional development in nowadays, the conceptual principles of reforming general secondary educa- tion in Ukraine («New Ukrainian School») indicates the need to reform not only forms and methods of teacher training, but also making significant changes in the content of curricula and programs. It is necessary to create new organizational ways for it.

Way 1. Formation of the teacher professional development plan. According to Part 3 of Article 59 by the Law of Ukraine «On Education» pedagogical (academic) council of the educational institution on the basis of proposals of pedagogical (scientific) staff approves the annual plan of professional development for pedagogical (scientific) staff (with or without separation from the educational process). In modern conditions, the subjects of the process of professional development can be not only institutions of postgraduate pedagogical education, but also could be all educational institutions that have a license for professional development or conduct educational activities under an accredited educational program. The results of professional development in such educational institutions do not need separate recognition and confirmation. There is a need to create an electronic register of organizations that have the right to provide services in the field of professional development of pedagogical (scientific) staff and creation a web portal to receive objective information by each teacher, staff or Head of organization, for approving the teacher professional development. The presence of such web portal would simplify the cooperation with the financial authorities (Luniachek, 2017).

Way 2. Financing of teacher professional development. Part 5 of Article 59 by the Law of Ukraine «On Education» notes that the total number of hours devoted to professional development of pedagogical (scientific) staff, paid from the relevant budgets, is determined by law. Funds for professional development of pedagogical (scientific) staff are received by the educational institution, which distributes it by the decision of the pedagogical (scientific) council of the educational institution. Professional development of a pedagogical (scientific) staff can be financed by the founder of the educational institution, the educational institution in which he/she works the pedagogical (scientific) employee, as well as other individuals and legal entities. At the same time, in the context of the implementation of Part 4 of Section XII «Final and Transi- 
tional Statements» of the Law of Ukraine «On Education», was added by the Part 3 of Article 27 of the Law of Ukraine «On General Secondary Education» about annual teacher professional development. The total number of academic hours for professional development of a pedagogical staff for five years may not be less than 150 hours, of which a certain number of hours must be aimed at improving knowledge, skills and practical ability in working with pupils with special educational needs (Luniachek, 2017).

Until now, the procedure of teacher professional development financing was carried out through the regional budgets for institutions of postgraduate pedagogical education. Local budgets provided only funds for business trips of teachers to the regional centre. In the conditions of diversification of postgraduate pedagogical education the situation has fundamentally changed.

Way 3. Change of forms for professional development. Part 1 of Article 59 by the Law of Ukraine «On Education» states that the professional development of pedagogical and scientific staff provides, including, in addition to participation in training programs, any other types and forms of professional growth. Part 2 of Article 59 by the Law of Ukraine «On Education» states that professional development can be carried out in different types (educational program, internship, participation in certification programs, trainings, seminars, workshops, seminars-meetings, seminars-trainings, webinars, workshops, etc.) and in various forms (institutional, dual, in the workplace, etc.).

The modern practice of professional development of pedagogical staff takes place mainly according to the traditional scheme - lecture, workshop, field trip, etc. Innovative forms of professional development using interactive technologies are quite limited. That is why it is becoming more important to improve skills through the transfer of pedagogical and managerial technologies in the field of education. Technology transfer involves the granting of the right to use intellectual property, the transfer of technological documentation, information exchange, the involvement of skilled workers with special knowledge (Luniachek, 2017).

In Ukraine, there is still no common database where pedagogical technologies and methods are concentrated, which is the main scientific component for defended $\mathrm{PhD}$ and doctoral dissertations in pedagogy. The urgent need is not only its creation, but also the development of procedures for commercial and non-commercial transfer of these technologies. The relevant database bank should become a component of the national electronic portal on professional development. This will allow the teacher not just to listen the course of lectures in the process of professional development, but to master a new technology or methodology in the direction of own work, to actually implement the principle of scientificity. This is especially true for the category of experienced teachers and educators who already have solid professional achievements.

The remote form of professional development for pedagogical and managerial staff of education should be further developed. Today, the process of distance education in the field of professional development is in fact an element of electronic support for the process of professional development and does not meet the classical requirements of distance education. As a rule, it involves downloading certain text materials, performing practical work, etc. At the same time, the process of communication does not take place due to the opportunities provided by modern distance learning systems, the possibilities of virtual tools are not used, and so on.

Way 4. Change of mentality. The implementation of this way is the most difficult task, because it involves overcoming the traditional formalized approach for teacher professional development. An important role in this process is given to the Heads of educational institutions. The implementation of educational reforms largely depends on their personal position. In this regard, it is important to inform teachers about the changes provided by the Law of Ukraine «On Education». This is especially needs for the pedagogical community of remote country communities. New ways for teacher professional development and their capabilities should be proven to Heads of education at all levels, and through them to every teacher. The popularization of these approaches through the Internet, etc. is gaining considerable attention (Luniachek, 2017).

At the same time, every pedagogical worker and head of education must answer the question why he/her chose this or that form of pro- 
fessional development, how it will actually affect the process of his/her certification, what he/her should require from the organization that provides him/her the educational services. Based on this, a change in the mentality of the service consumer will occur due to a change in his/her motivation. At the same time, there is a question of evaluating the results of the professional development process, which will partially involve changes in the ways of teacher certification, as well as affect the processes of their certification, which are just in the beginning. The teacher must not only be aware of his/her professional needs, but also understand how it will affect the realization of his/her professional career goals.

In Ukrainian science emphasizes that the effective teacher professional development could be in terms of their active involvement in its planning, cooperation, reflection and combination of theory and practice. Ukrainian scientist $T$. Sorochan defines the following principles of teacher professional development in the regional system of postgraduate pedagogical education, namely: the use of a lifelong competence approach in the development of teacher professionalism; formation the ability of teachers to work in an innovative environment; ensuring partnership and professional interaction in the learning process; facilitation in mastering the methods of independent search for knowledge in various fields of science and culture, theory and practice; application of diagnostics and monitoring of the development level of own professionalism (Sorochan, 2010, p. 13).

In 2020, the Ministry of Education and Science of Ukraine developed a draft Regulation on the Centre for Teacher Professional Development. The system of centres for professional development should replace the existing methodical offices. The purpose of creating professional development centres is to promote the teacher professional development of preschool, out-of-school, secondary education, inclusive resource and inter-school resource centres (Education Reform, 2020). The need for such development is dictated by the global principle of lifelong learning, which allows remaining a competitive specialist, and
Ukrainian educational reforms that require professional teachers. It is planned that the Centres of Professional Development will provide advisory and guidance support to teachers on professional development, supervision, documentation of the institution, educational and training programs, organization of the educational process. The promotion of teacher professional development will be carried out, in particular through the coordination of professional communities, dissemination of information on professional development, the formation of databases of in-service training programs and sources necessary for professional development. In addition, the Centres will be responsible for the teacher psychological support. The founders of the Centres can be district, city (district in the city) councils. Several founders can jointly form a centre and conclude an agreement on joint activities (Education Reform, 2020).

Conclusions. Analysis of the teacher professional activity allows doing conclusions about teacher professional development. The teacher professional development affects the level of own professional activity and is characterized by the acquisition of competencies. That is why, for better efficiency of teacher professional development in Ukraine it is necessary: 1) The full implementation of the Law of Ukraine «On Education» to improve the skills of teachers, that requires the development of a number of organizational mechanisms aimed at achieving the goals. These mechanisms can be created at both the national and local levels. 2) An important component of reforms is to bring information directly to the consumer (teacher, pedagogical staff etc.) of professional development services, both in the traditional way and through the Internet. 3) The introduction of new mechanisms for professional development that requires the support of a number of bylaws and the development of new forms of documentation in this area, including elements of financial reporting. 4) Diversification of forms and methods of teacher professional development that requires strengthening their motivational component for representatives of the educational field.

\section{REFERENCES}

Chernii, A. (2018). Teacher professional development: experience, cooperation, priorities on the way to the New Ukrainian School. Postgraduate education in Ukraine (December), 40 URL: 
http://umo.edu.ua/images/content/nashi vydanya/pislya dyplom osvina/2 2018/\%D0\%9F\%D0 \%9E $22018 \%$ D0\%A7\%D0\%95\%D0\%A0\%D0\%9D\%D0\%98\%D0\%99.pdf (in UA).

Education Reform. (2020). In Ukraine will create the Centres of Teacher Professional Development. Web portal osvita.ua. URL: https://osvita.ua/school/reform/73662/ (in UA).

Kremen, V. H. (Ed.). (2008). Encyclopedia of Education. Kyiv, Ukraine: Yurinkom Inter. (in UA).

Law of Ukraine: On Education. №2145-VIII (2017).URL: https://zakon.rada.gov.ua/laws/show/2145-19

Law of Ukraine: On General Secondary Education. №463-IX. (2020). URL: https://zakon.rada.gov.ua/laws/show/463-20\#Text

Lukianova, L. (2020). Adult education in Ukraine: preconditions of formation, prospects of development. UNESCO Chair Journal on Lifelong Professional Education in the XXI Century, 1, 17-21. URL: https://doi.org/10.35387/ucj.1(1).2020.17-21

Luniachek, V. (2017). Teacher professional development: new opportunities of the Law of Ukraine «On Education». Educational Policy: a portal of public experts. URL: http://educationua.org/ua/articles/1085-profesijnij-rozvitok-vchitelya-novi-mozhlivosti-yaki-vidkrivae-zakonukrajini-pro-osvitu (in UA).

Sorochan, T. M. (2010). Create an educational space for professional development. Education Management, 17, 13-15 (in UA).

Statement: On Centers for Teacher Professional Development. №672-2020-п. (2020) URL: https://zakon.rada.gov.ua/laws/show/672-2020-\%D0\%BF\#Text

Кирил Котун, кандидат педагогічних наук, старший науковий співробітник відділу зарубіжних систем педагогічної освіти і освіти дорослих Інституту педагогічної освіти і освіти дорослих імені Івана Зязюна НАПН України.

Kyryl Kotun, PhD in Pedagogy, Senior Research Staff of Department of Foreign Pedagogical and Adult Education Systems at Ivan Ziaziun Institute of Pedagogical and Adult Education of NAES of Ukraine.

E-mail: smartk@ukr.net

ORCID ID 0000-0002-3661-6689

Received: 03.10.2020

Accepted: 09.11.2020 